\title{
The issue of decisiveness in the COVID-19 outbreak in Korea
}

\author{
Author: Kyoo-Man $\mathrm{Ha}^{\mathrm{A}}$
}

Based on five stakeholders (the central government, local governments, hospitals, businesses and local communities), the Republic of Korea must shift from its current indecisive approach to a decisive approach to the COVID-19 outbreak. Other nations should also consider the issue of decisiveness before it is too late.

KEYWORDS: coronavirus infection, indecisive approach, decisive approach, time interval, pandemic management

DOI: 10.7861/clinmed.2021-0558

\section{Introduction}

Decisiveness refers to the capacity of individuals or organisations to quickly and effectively make a series of decisions on COVID-19, consequently resolving related contentious issues and achieving productive results in the field. ${ }^{1}$ Towards this end, two opposite approaches can be applied. Under the indecisive approach, stakeholders may not have the ability to make timely decisions on COVID-19; thus, it is almost impossible to progress in the fight against COVID-19 by relying on this approach. In contrast, under the decisive approach, stakeholders would be capable of resolving the COVID-19 outbreak within a shorter period of time.

Herein, this commentary aims to raise the significance of decisiveness in dealing with the COVID-19 outbreak in the Republic of Korea (South Korea) through a comparison between the indecisive and the decisive approach. Both approaches are systematically examined by considering five important stakeholders in South Korea; the central government, local governments, hospitals, businesses and local communities. The key finding is that South Korea needs to shift from its current indecisive approach to the decisive approach toward achieving the ultimate goal of pandemic management.

\section{Indecisive approach}

In the first month or so after the outbreak of COVID-19 in South Korea, top government officials erroneously believed that the central government could deal with the issue by relying on its own strategies (Table 1). ${ }^{2,3}$ The Ministry of Health and Welfare

Author: ${ }^{A}$ adjunct professor, Inje University, Gimhae City, Korea
$(\mathrm{MOHW})$, as a single institution, played a major role in the response to the outbreak. Some politicians in the ruling party were quick to commend the central government and the president on how well they were handling the COVID-19 outbreak.

The majority of local governments did not exert distinctive efforts to address the issue of the COVID-19 outbreak. They believed that COVID-19 would be resolved by either China or hospitals in South Korea. In Daegu, even as the number of infected patients sharply increased due to the spread of the virus during religious gatherings, the city mayor refused to take immediate action against religious groups, such as the Shincheonji Church of Jesus. Moreover, the Chungnam and Gangwon provincial governments continued to ship face masks to China despite acknowledging the sharp demand in their own local areas.

Although the central government initiated actions to address the COVID-19 outbreak, medical doctors in general were not allowed to participate equally in the related decision-making process due to political conflicts. Hence, their professional opinion was not reflected in the resultant government policy. In Cheongdo-gun, Daenam Hospital failed to prevent the spread of the virus among patients after infected members of the Shincheonji Church of Jesus were admitted to the facility.

To stem the outbreak of COVID-19, people require hygiene products (such as face masks, hand sanitisers and soaps) on a daily basis. Thus, the demand for these products has increased significantly in South Korea since the outbreak. However, despite having gauged the potential demand based on the situation in China, local companies failed to produce sufficient supplies of face masks for South Korea. Eyeing greater economic benefits, some manufacturers prioritised exporting face masks to China over selling to South Korean markets. Other companies withheld their supplies in their warehouses to push prices upward.

To aggravate the situation, some infected residents failed in terms of truthfulness, transparency and responsibility in divulging information about their symptoms, travel history and other relevant data; for example, the church minister Jeon Kwanghoon insisted on holding political rallies in public places, such as Gwanghwamun, even during the emergency response, and a few churches continued with their Sunday church services.

\section{Decisive approach}

Recognising the rapidly deteriorating situation due to COVID-19 in neighbouring nations (such as China and Japan), the South Korean central government should have reacted more decisively 
Table 1. Some empirical evidence for the indecisive approach ${ }^{2,3}$

$\begin{array}{ll}\begin{array}{l}\text { Stakeholders } \\ \text { Central government }\end{array} & \begin{array}{l}\text { Empirical evidence } \\ \text { The central government did not swiftly make vaccine purchase contracts with international pharmaceutical } \\ \text { companies until the second quarter of 2021. }\end{array} \\ \text { Local governments } & \begin{array}{l}\text { About } 8.5 \% \text { of local employees }(97 / 1,143) \text { at the Guro-gu call-centre were confirmed to have COVID-19 in } \\ \text { March } 2020 .\end{array} \\ \text { Hospitals } & \begin{array}{l}\text { A number of medical doctors quit their jobs at public health centres in July } 2020 \text { (1/3 at Gwanak-gu and } \\ \text { Gangdong-gu), partly due to their exclusion from the COVID-19 decision-making process. }\end{array} \\ \text { Businesses } & \begin{array}{l}\text { Public prosecutors recorded } 301 \text { cases related to COVID-19 in March 2020, } 72.8 \% \text { ( } n=219) \text { of which were } \\ \text { associated with businesses' strategies toward face masks. } \\ \text { Local communities }\end{array} \quad \begin{array}{l}\text { More than } 500 \text { people were confirmed to have been infected by COVID-19 after the Gwanghwamun rally led } \\ \text { by Jeon Kwang-hoon in mid-August } 2020 .\end{array}\end{array}$

to the outbreak. In particular, the knowledge that the pandemic emergency may affect anyone anywhere should have led to the realisation that it is impossible for a single institution, such as the South Korean central government, to deal efficiently with the various impacts of the coronavirus outbreak.

Local governments, being considered as the first line of defence against a pandemic emergency, should have monitored the spread of COVID-19 in local communities from the very beginning. ${ }^{4}$ In regions where an outbreak has not yet taken place, local governments must prepare for its potential occurrence. Once an outbreak does take place in communities, they should decisively respond by fully utilising all personnel, resources, strategies and outside support.

Medical doctors should have maintained a good relationship with authorities in the central government or political arena. Like it or not, the activities of modern professionals have been much decided by political interests. By raising the tone of political voice in society, medical doctors will further respond to COVID-19. Therefore, Daenam Hospital must faithfully carry out its original mandate to rigorously deal with the COVID-19 pandemic, despite having a direct or indirect association with a religious group.

Regarding their role in emergency management, businesses should have monitored the supply of face masks in the South Korean and overseas markets and should have maintained sufficient reserves in view of the COVID-19 outbreak. Stockpiling, rather than price manipulation, may be one of the best ways for them to reap economic benefits in the harsh field of emergency management.

Local communities include not only religious groups but also local residents, foreign-born employees and the mass media, among others. To slow down community transmission, all these communities must cooperate with emergency responders by their timely sharing of truthful information on COVID-19. In particular, religious leaders as super spreaders must not consider the outbreak of COVID-19 as a specific religious issue but as a universal national concern.

\section{Discussion}

The key finding is that South Korea must shift from its current indecisive approach to a decisive one in order to adequately deal with the COVID-19 outbreak. The indecisive approach is incapable of efficiently decreasing the impacts of the coronavirus infection.
Under the decisive approach, the five stakeholders considered herein must carry out specific responsibilities, such as providing updated information on the pandemic, fostering emergency preparedness, building good relations with the government, maintaining stockpiles of necessities and cooperating with other entities.

The time interval between the decision making at the top level and the movement to safety of individuals at the bottom level is crucial. ${ }^{5}$ Time is key in pandemic management. In particular, when an epidemic breaks out in a region, the related infection quickly spreads in society. Accordingly, the phase of emergency response to a pandemic is relatively shorter than the phases of emergency mitigation, preparedness and recovery. Therefore, the decisive approach is absolutely necessary in the field, regardless of geographical boundaries.

The transition to the decisive approach may provide valuable lessons for other nations in terms of the wide range of COVID-19 transmissibility. In particular, nations in which the extent of SARS-CoV-2 infection has not been as severe (such as in South America, Africa and South Asia) must consider the significance of the decisive approach, supported by pandemic management, while the community spread of COVID-19 in their areas is still manageable.

\section{References}

1 Norheim OF, Abi-Rached JM, Bright LK et al. Difficult trade-offs in response to COVID-19: The case for open and inclusive decision making. Nat Med 2021;27:10-3.

2 Ministry of Health and Welfare (MOHW). www.mohw.go.kr/react/ index.jsp

3 Ministry of the Interior and Safety (MOIS). www.mois.go.kr/frt/a01/ frtMain.do

4 National Governors Association Center for Best Practices. Preparing for a pandemic influenza: a primer for governors and senior state officials. NGA Center for Best Practices, 2006.

5 Toner E, Waldhorn R. What US hospitals should do now to prepare for a COVID-19 pandemic. Clinicians' Biosecurity News 2020. www. centerforhealthsecurity.org/cbn/2020/cbnreport-02272020.html

Address for correspondence: Dr Kyoo-Man Ha, Department of Emergency Management, Inje University, 197 Inje-ro, Gimhae City, Gyeongnam 50834, Republic of Korea. Email: ha1999@hotmail.com 